\title{
EFFECT OF GIBBERELLIN ON GROWTH AND DEVELOPMENT OF Spondias tuberosa SEEDLINGS ${ }^{1}$
}

\author{
FÁBIO SANTOS MATOS ${ }^{2 *}$, IGOR ALBERTO SILVESTRE FREITAS ${ }^{3}$, VICTOR LUIZ GONÇALVES PEREIRA ${ }^{3}$, \\ WINY KELLY LIMA PIRES ${ }^{3}$
}

\begin{abstract}
The development of technologies will certainly contribute to boost the commercial exploitation and domestication of Spondias tuberosa. The objective of the present study was to identify morphophysiological effects of gibberellin on the growth of $S$. tuberosa seedlings. The experiment was conducted in a greenhouse at the Goiás State University, Brazil, using 300-day-old S. tuberosa seedlings planted in 12-liter pots containing soil (Typic Hapludox), sand, and manure (3:1:0.5). The experiment was conducted in a completely randomized design, with five replications and six treatments consisting of single foliar applications of $30 \mathrm{~mL}$ plant ${ }^{-1}$ of solutions with different gibberellin $\left(\mathrm{GA}_{3}\right)$ concentrations $(0,150,300$, 450, 600, and $750 \mathrm{mg} \mathrm{L}^{-1}$ ), using a manual sprayer. The plants were evaluated at 60 days after the applications. The maximum biomass accumulation in $S$. tuberosa seedlings was found with the use of $415 \mathrm{mg} \mathrm{L}^{-1}$ of $\mathrm{GA}_{3}$. The use of gibberellin accelerated the vegetative growth of $S$. tuberosa plants and enabled the formation of seedlings with better root system and xylopodium, and aerial parts with greater number of leaves, leaf area, and stem weight.
\end{abstract}

Keywords: Phytohormones. Caatinga biome. Endemic. Umbuzeiro.

\section{EFEITO DA GIBERELINA NO CRESCIMENTO E DESENVOLVIMENTO DE MUDAS DE Spondias tuberosa}

RESUMO - O desenvolvimento de tecnologias de cultivo certamente contribuirá para alavancar a exploração comercial e domesticação de Spondias tuberosa. O presente estudo teve como objetivo identificar os efeitos morfofisiológicos da giberelina no crescimento de mudas de $S$. tuberosa. O trabalho foi conduzido em casa de vegetação na Universidade Estadual de Goiás, Brasil. Utilizaram-se plantas de umbuzeiro oriundas de sementes com 300 dias de idade em vasos de 12 litros contendo uma mistura de solo, areia e esterco na proporção de 3:1:0,5 respectivamente. $\mathrm{O}$ experimento seguiu o delineamento inteiramente casualizado, com seis tratamentos e cinco repetições caracterizados pelo uso de giberelina nas concentrações de $0 ; 150 ; 300 ; 450 ; 600$ e $750 \mathrm{mg} \mathrm{L} \mathrm{L}^{-1}$ em volume de $30 \mathrm{ml} /$ planta em aplicação única via foliar com auxílio de borrifador manual. As análises foram realizadas aos 60 dias após a imposição dos tratamentos. O máximo acúmulo de biomassa em mudas de umbuzeiro ocorreu com aplicação de $415 \mathrm{mg} \mathrm{L}^{-1}$ de $\mathrm{GA}_{3}$. A giberelina acelerou o crescimento vegetativo das plantas e permitiu a formação de mudas com sistema radicular e xilopódio robustos, parte aérea vigorosa com maior número de folhas, área foliar e massa caulinar.

Palavras-chave: Fitohormônios. Bioma Caatinga. Endêmica. Umbuzeiro.

\footnotetext{
${ }^{*}$ Corresponding author

${ }^{1}$ Received for publication in 08/07/2019; accepted in 07/27/2020.

Paper extracted from the master's dissertation of the second author.

${ }^{2}$ Department of Plant Production, Universidade Estadual de Goiás, Ipameri, GO, Brazil; fabio.agronomia@hotmail.com - ORCID: 00000002-7666-006X.

${ }^{3}$ Plant Production Physiology Sector, Universidade Estadual de Goiás, Ipameri, GO, Brazil; igor alberto99@hotmail.com - ORCID: 00000002-1967-027X, victorluiz1998@outlook.com - ORCID: 0000-0001-7573-3047, winykelly@outlook.com - ORCID: 0000-0001-87597732 .
} 


\section{INTRODUCTION}

The fruit sector is important to the Brazilian agribusiness; fruit production for fresh consumption and processing industries (juices and nectars) has continuously grown in Brazil. Brazil is the third largest word fruit producer, with 40 million $\mathrm{Mg}$ year ${ }^{-}$ ${ }^{1}$ of fruits grown in an area of 2.3 million hectares. This sector generates 5.6 million direct jobs, representing $27 \%$ of the agricultural workforce in the country (BRASIL, 2018).

Despite the high production of the Brazilian fruit sector, it can still grow and generate even more jobs through the commercial exploitation of native species such as Spondias tuberosa Arruda (NUNES et al., 2018). This species has high economic potential; its fruits can be consumed fresh or in drinks, sweets, jellies, and ice creams, and are appreciated by consumers of several Brazilian states (PIRES, 2018).

$S$. tuberosa is indigenous to the Caatinga biome, which is found only in Brazil; this biome covers $70 \%$ of the Northeastern region of Brazil and $11 \%$ of the Brazilian territory (LIMA; SILVA; OLIVEIRA, 2018) and is characterized by long drought periods, with average rainfall of $600 \mathrm{~mm}$ year $^{-1}$ concentrated between February and May (SOUZA; MENEZES; ARTIGAS, 2015). S. tuberosa is a perennial arboreal species of the Anacardiaceae family; it reaches heights of approximately $7 \mathrm{~m}$ and canopy diameter of approximately $12 \mathrm{~m}$. This is a xerophilous, deciduous plant that is adapted to hot environments and soils with different fertility levels and has agricultural potential, since it grows well under temperatures between $12{ }^{\circ} \mathrm{C}$ and $38{ }^{\circ} \mathrm{C}$ and insolation periods of 2,000 to 3,000 hours year ${ }^{-1}$ (MERTENS et al., 2016).

Some plants develop spongy xylopodia and tuber structures next to secondary roots, near the trunk, as part of their root system; these structures store nutrients and water, which are important for plant survival in drought periods (SATURNINO et al., 2019). S. tuberosa produces approximately 300 $\mathrm{kg}$ of fruits per harvest; the fruit weights are between 10 and $20 \mathrm{~g}$, however, there is a significant variation between plants, especially for the giant $S$. tuberosa, which presents higher yields and fruits of approximately $150 \mathrm{~g}$ (DONATO et al., 2019a; SANTOS et al., 2018).

S. tuberosa has a long cycle, with a productive life of approximately 100 years, thus, its initial growth is slow (LIMA; SILVA; OLIVEIRA, 2018). This plant has a long juvenile phase: seedlings from seeds and grafted seedlings reach productive stage at 10 and 6 years after planting, respectively. The slow initial growth and long juvenile stage of this plant discourage investments on the production of $S$. tuberosa due to the long-term economic return (CAVALCANTI et al., 2015).
The use of plant hormones to improve vegetative growth and shorten the juvenile phase of $S$. tuberosa is little studied, but it can be an important management practice for this species. According to Donato et al. (2019b), gibberellin intensifies vegetative growth of $S$. tuberosa seedlings by generating plants with vigorous root systems, thick and long stems, and abundant leaf areas.

Domestication of $S$. tuberosa is incipient; it has been produced by extractivism, with few plantations using superior materials (LINS NETO et al., 2013). Extractivism is not a sustainable form of income, and the lack of specific techniques for growing this plant species makes the production of its fruits even more dependent on environmental conditions. The development of agricultural practices and the availability of technologies, such as growth regulators, can improve commercial production and domestication of $S$. tuberosa.

The tolerance of $S$. tuberosa to droughts occurs at the expense of the positive hormonal balance that controls stress and is unfavorable to plant growth. Thus, the use of a growth stimulator and an adequate water balance can reduce the plant's juvenile period and contribute to the development of more productive plants in a shorter time. In this context, the objective of this work was to identify morphophysiological effects of gibberellin on the growth of $S$. tuberosa seedlings.

\section{MATERIAL AND METHODS}

The experiment was conducted in a greenhouse covered with transparent plastic on the top and 50\% shade screens on the sides, at the Goias State University, in Ipameri, Goiás, Brazil. The region has an Aw, tropical climate with dry winter and wet summer, according to the Köppen classification, with average annual temperature of $20{ }^{\circ} \mathrm{C}$ (ALVARES et al., 2013). S. tuberosa seedlings of 300 days old were planted in 12-liter pots containing Typic Hapludox soil (EMBRAPA, 2013), sand, and manure (3:1:0.5). After soil chemical analysis, lime and fertilizers were applied following the recommendations of Cruz, Andrade and Feitosa (2016). The plants were irrigated daily, using water depths that corresponded to the retention capacity of the substrate, determined by the pot weights.

The experiment was conducted in a completely randomized design, with five replications and six treatments. The treatments consisted of two foliar applications with a 30-day interval: $30 \mathrm{~mL}$ plant $^{-1}$ of solutions with different gibberellin $\left(\mathrm{GA}_{3}\right)$ concentrations $(0,150,300,450,600$, and $\left.750 \mathrm{mg} \mathrm{L}^{-1}\right)$ were applied using a manual sprayer. The plants were evaluated at 60 days after the applications. 


\section{Variables}

Plant height was measured from the stem base to the top, using a ruler. The stem diameter was measured at the stem base, using a digital caliper. Number of leaves was counted. Root length was measured using a graduated line. Leaf area was determined using an area meter device (LI-3100; LiCor, Lincoln, USA) and was expressed in $\left(\mathrm{cm}^{2}\right)$. Destructive analyses of roots, xylopodia, stems, and leaves were conducted; these structures were separated and dried in an oven at $72{ }^{\circ} \mathrm{C}$ until constant weight.

The dry weight data were used to calculate the following variables: total biomass, by adding the weight of all plant parts; and root weight ratio, stem weight ratio, and leaf weight ratio, by dividing the weight of each plant part by the total biomass. Six leaf discs of $1.2 \mathrm{~cm}$ diameter were dried in an oven, and the six-disc area was divided by the six-disc dry weight to determine the specific leaf area.

Chlorophyll concentration was determined using leaf discs removed from the known area; they were placed in containers with dimethyl sulfoxide, and the extraction was carried out in a water bath at $65{ }^{\circ} \mathrm{C}$ for one hour. Aliquots were subjected to spectrophotometric readings at 480, 646, and $665 \mathrm{~nm}$. Chlorophyll a $(\mathrm{Cl} a)$ and chlorophyll b $(\mathrm{Cl} b)$ contents were determined following the equation proposed by Wellburn (1994).

Epidermal replicas of the leaf adaxial and abaxial surfaces were made through impressions obtained by coating the middle third region of previously dehydrated leaves with clear nail polish. The stomata in the replicas were counted with the aid of an optical microscope equipped with a camera lucida. Stomatal density was determined by counting the stomata in an area of $1 \mathrm{~mm}^{2}$. Five replicas of the leaf adaxial and abaxial surfaces of each replication were analyzed to determine the stomatal density, following recommendations of Borges et al. (2014).

The data were subjected to analysis of variance and to linear and quadratic regression analysis; when the means of the regression analysis were significance by the $\mathrm{F}$ test, the coefficient of determination $\left(\mathrm{R}^{2}\right)$ was calculated by the ratio between the sum of squares of the regression and the total sum of squares. Multivariate analysis was carried out by multiple regressions, using the forward stepwise model (SOKAL; ROLPH, 1995). Principal component analysis was used with a permutational multivariate analysis of variance (PERMANOVA - ANDERSON, 2001). The R
(R CORE TEAM, 2018) and SigmaPlot 10.0 (SYSTAT SOFTWARE, 2006) programs were used for the analyses.

\section{RESULTS AND DISCUSSION}

The evaluated variables presented normal distribution, and those that significantly fitted to the regression models by the F test are shown in Figures 1,2 , and 3. Spondias tuberosa plants presented $99 \%$ of the stomata in the abaxial epidermis, but the number of stomata, root weight ratio, and leaf weight ratio did not significantly fit to linear or quadratic regression models (data not shown).

The increases in gibberellin $\left(\mathrm{GA}_{3}\right)$ concentrations increased plant biomass, plant height, stem diameter, and leaf area (Figure 1), with peaks at the concentrations of $415,390,370$, and $413 \mathrm{mg} \mathrm{L}^{-1}$, respectively. The $\mathrm{GA}_{3}$ applied affected positively the growth of $S$. tuberosa plants and intensified cellular elongation, as shown by a pronounced development of roots, stems, and leaves.

The induction of cell expansion caused by gibberellin occurs through a chemical signaling that causes greater activity of the xyloglucan endotransglucosylase enzyme, which breaks down hemicellulose-cellulose bindings and reduces the interaction between these polysaccharides for later action of expansins that loosen the cell wall and move the cellulose microfibrils away for cell expansion (TAIZ et al., 2017).

The chemical signaling of gibberellin probably occurs synergistically and additively to the action of auxins that activate $\mathrm{H}^{+}$-ATPases and make the appropriate medium for the activity of expansins. The increase in vegetative growth of young eucalyptus plants treated with gibberellin has generated good perspectives for the commercial use of this growth regulator in other woody species (AMARO et al., 2017; LOPES et al., 2015).

The increasing $\mathrm{GA}_{3}$ concentrations resulted in increases in leaf chlorophyll content, carotenoid content, root length, and xylopodium length, with fit to the quadratic model, presenting peaks at the concentrations of $396,448,390$, and $412 \mathrm{mg} \mathrm{L}^{-1}$, respectively (Figure 2). In addition to stimulating cell expansion, gibberellins are possibly chemical messengers for the action of other hormones, such as auxin, cytokinins, and brassinosteroids, which increase emergence of leaf primordia and growth of roots and xylopodia for maximizing absorption and storage of nutrients from the soil solution. 

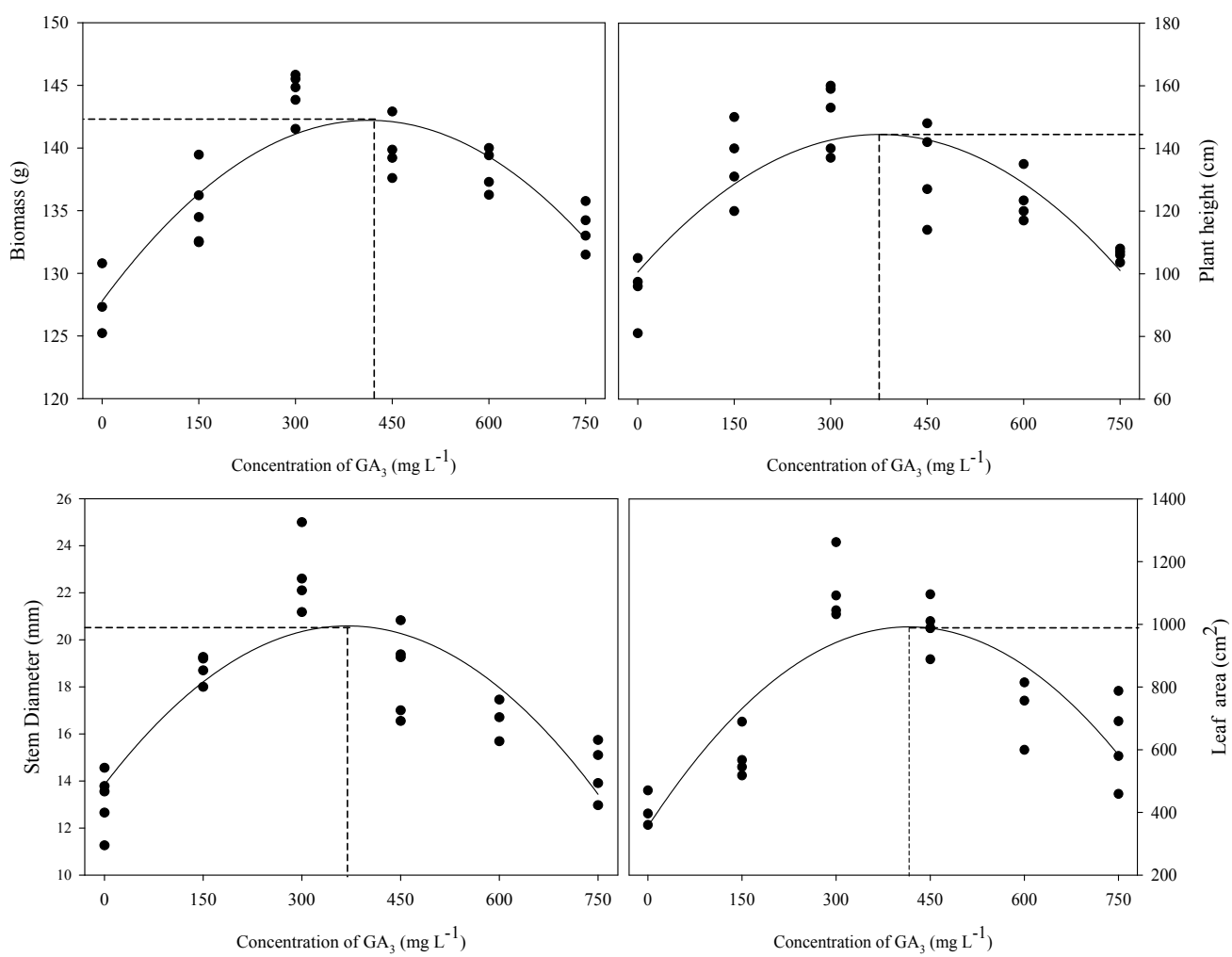

Figure 1. Regression equations for biomass $\left(\mathrm{Y}=127.78+0.070 \mathrm{x}-0.0000841 \mathrm{x}^{2}, \mathrm{R}^{2}=0.75^{* *}\right)$, plant height $(\mathrm{Y}=100.53+$ $\left.0.234 \mathrm{x}-0.0003 \mathrm{x}^{2}, \mathrm{R}^{2}=0.70 * *\right)$, stem diameter $\left(\mathrm{Y}=13.8419+0.037 \mathrm{x}-0.000049 \mathrm{x}^{2}, \mathrm{R}^{2}=0,71 * *\right)$, and leaf area $(\mathrm{Y}=$ $\left.354.95+3.06 \mathrm{x}-0.0037 \mathrm{x}^{2}, \mathrm{R}^{2}=0,70^{* *}\right)$ of Spondias tuberosa plants grown under different concentrations of $\mathrm{GA}_{3}(0,150$, $300,450,600$, and $\left.750 \mathrm{mg} \mathrm{L}^{-1}\right)$.
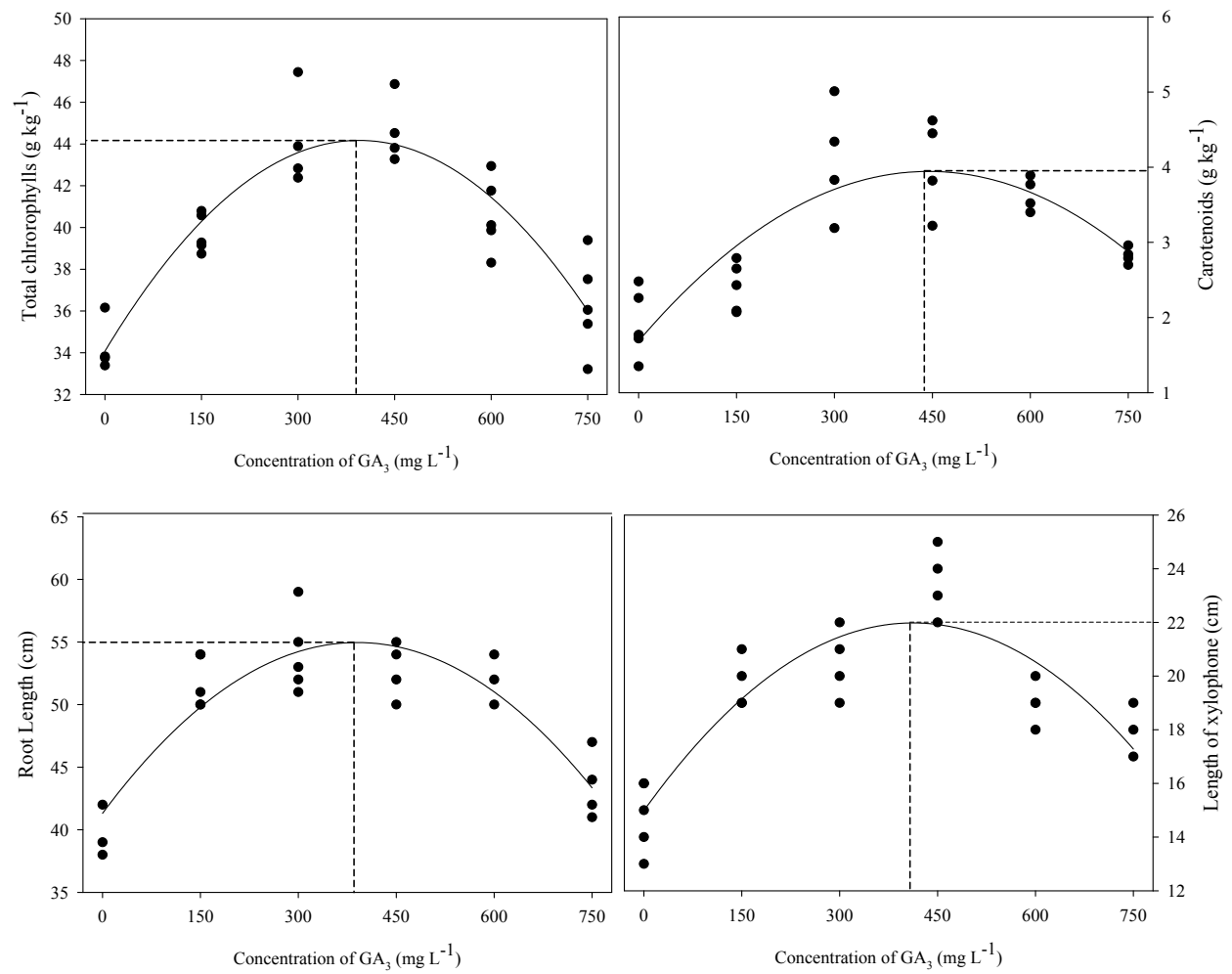

Figure 2. Regression equations for total chlorophyll $\left(\mathrm{Y}=34.073+0.0512 \mathrm{x}-0.000065 \mathrm{x}^{2}, \mathrm{R}^{2}=0.82^{* *}\right)$, carotenoids $(\mathrm{Y}=$ $\left.1.69+0.010 \mathrm{x}-0.000011 \mathrm{x}^{2}, \mathrm{R}^{2}=0,70^{* *}\right)$, xilopodium length $\left(\mathrm{Y}=14.98+0.034 \mathrm{x}-0.000041 \mathrm{x}^{2}, \mathrm{R}^{2}=0,76^{* *}\right)$, and root length $\left(\mathrm{Y}=41.31+0.070 \mathrm{x}-0.00009 \mathrm{x}^{2}, \mathrm{R}^{2}=0.78^{* *}\right)$ of Spondias tuberosa plants grown under different concentrations of $\mathrm{GA}_{3}\left(0,150,300,450,600\right.$, and $\left.750 \mathrm{mg} \mathrm{L}^{-1}\right)$. 
The hormones abscisic acid (activator of the water stress resistance system) and ethylene (activator of the deciduous process) were possibly suppressed and growth hormones were activated due to the use of $\mathrm{GA}_{3}$. Hormonal balance is certainly important for these processes. Gibberellin, auxin, brassinosteroid, and cytokinin hormones have important functions and reciprocal interactions in the processes of cell division and expansion and tissue differentiation (BJÖRKLUND, 2007; WEISS; ORI, 2007).

The use of an adequate water supply generated no stomatal limitation for $\mathrm{CO}_{2}$ influx and, consequently, increased photosynthesis for production of assimilates to compensate the vegetative growth. Carotenoids probably had an accessory pigment function to chlorophylls in the absorption of light energy for increasing photosynthesis. According to Cruz, Andrade and Feitosa (2016), increases in number of leaves and length of roots and xylopodia positively affect photosynthetic rates.

The use of $\mathrm{GA}_{3}$ resulted in a linear increase in specific leaf area (SLA), and the number of leaves and stem weight ratio fitted to the quadratic model (Figure 3), with peaks at $\mathrm{GA}_{3}$ concentrations of 399 and $349 \mathrm{mg} \mathrm{L}^{-1}$, respectively. The increases in SLA were consistent with the increases in vegetative growth (number of leaves, and stem and root weights) found by Porto et al. (2018) when studying fruit tree seedlings subjected to different gibberellin rates.
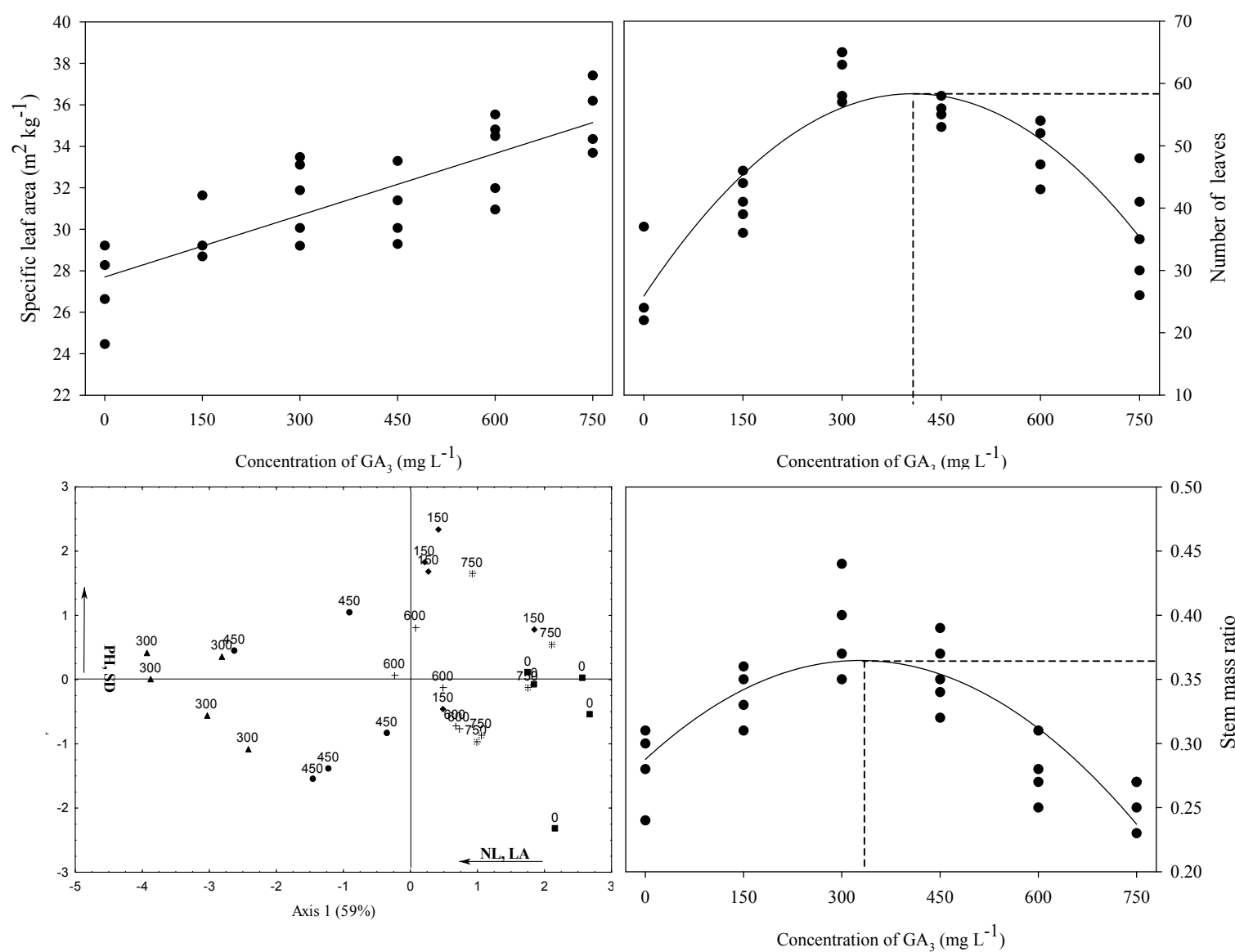

$\mathrm{PH}=$ Plant height, $\mathrm{SD}=$ stem diameter, $\mathrm{NL}=$ number of leaves and $\mathrm{LA}=$ leaf area

Figure 3. Regression equations for specific leaf area $\left(\mathrm{Y}=27.6990+0.0099 \mathrm{x}, \mathrm{R}^{2}=0.67 * *\right)$, number of leaves $(\mathrm{Y}=25.8835$ $\left.+0.1595 \mathrm{x}-0.0002 \mathrm{x}^{2}, \mathrm{R}^{2}=0,76^{* *}\right)$, stem mass ratio $\left(\mathrm{Y}=0,2876+0,0005 \mathrm{x}-7.17 \mathrm{x} 10^{-7} \mathrm{x}^{2}, \mathrm{R} 2=0.67 * *\right)$, and principal component analysis (PCA) for Spondias tuberosa plants grown under different concentrations of $\mathrm{GA}_{3}(0,150,300,450$, 600 , and $\left.750 \mathrm{mg} \mathrm{L}^{-1}\right)$.

Leaves with high SLA are thinner and present greater light transmittance through the canopy, thus minimizing the coefficient of extinction of solar radiation. In addition, formation of thinner leaves may be due to less investment by the plant in formation of woody tissues or secondary compounds of greater importance for resistance to stress but which are not necessary for plant growth.

The principal component analysis (PCA) explained $77 \%$ of the variance in the data and showed that the plant growth increased in the negative direction to axis 1 and positive direction to axis 2. The PCA formed a group composed of treatments with $\mathrm{GA}_{3}$ concentrations of 0,600 , and 
$750 \mathrm{mg} \mathrm{L} \mathrm{L}^{-1}$, which resulted in plants with lower growth, indicating that high gibberellin concentrations have no effect on plant growth; and another group composed of treatments with concentrations of 150,300 , and $450 \mathrm{mg} \mathrm{L}^{-1}$, which resulted in plants with higher growth. Therefore, the growth of $S$. tuberosa plants can be accelerated using $\mathrm{GA}_{3}$; however, high concentrations of $\mathrm{GA}_{3}$ limit the growth of $S$. tuberosa plants, probably due to the occurrence of negative responses. Moreover, the use of $\mathrm{GA}_{3}$ at a concentration of $750 \mathrm{mg} \mathrm{L}^{-1}$ resulted in less vigorous than those in the control treatment (without $\mathrm{GA}_{3}$ ).
The multiple regression model explained $82 \%$ of the variance in the $S$. tuberosa biomass (Table 1). Leaf area, stem diameter, and root weight ratio were the most important variables for total biomass. The results indicate that application of $\mathrm{GA}_{3}$ increases vegetative growth and accumulates biomass of $S$. tuberosa plants by directing assimilates to the formation of the root system, making it vigorous and maximizing the nutrient absorption. In addition, the application of $\mathrm{GA}_{3}$ increases the formation of stem and leaf area, increasing hydraulic conductivity and photosynthetic surface, respectively.

Table 1. Multiple regression model used to evaluate the effect of leaf area (LA), stem diameter (SD), root weight ratio (RWR), plant height $(\mathrm{PH})$, leaf carotenoid content (CAR), total chlorophyll content $(\mathrm{Chl} a+b)$, and xylopodium length $(\mathrm{XL})$ on the biomass of Spondias tuberosa plants grown under different concentrations of $\mathrm{GA}_{3}(0,150,300,450,600$, and $750 \mathrm{mg} \mathrm{L}^{-1}$ ).

\begin{tabular}{ccccccc}
\hline Biomass $(\mathrm{g})$ & $\mathrm{R}^{2}=0.82$ & $\mathrm{~F}(10.19)=8.75$ & $\mathrm{p}<0.0003$ & & & \\
& Beta & $\begin{array}{c}\text { Standard Error } \\
\text { Beta }\end{array}$ & $\mathrm{B}$ & $\begin{array}{c}\text { Standard Error } \\
\text { B }\end{array}$ & $\mathrm{t}(19)$ & $p$-level \\
\hline Intercept & & & -61.832 & 55.7513 & 1.10 & 0.28 \\
LA & 0.774 & 0.160 & 0.059 & 0.0123 & 4.816 & 0.000 \\
SD & 0.697 & 0.159 & 5.367 & 1.2292 & 4.366 & 0.000 \\
RWR & 0.611 & 0.125 & 279.339 & 84.4002 & 4.866 & 0.000 \\
PH & 0.531 & 0.168 & -0.469 & 0.1485 & -3.1580 & 0.005 \\
CAR & 0.382 & 0.143 & 7.860 & 2.9492 & 2.6652 & 0.015 \\
Chl $(a+b)$ & -0.718 & 0.202 & -3.254 & 0.9182 & -3.5441 & 0.002 \\
XL & 0.428 & 0.148 & 3.046 & 1.0535 & 2.8914 & 0.009 \\
\hline
\end{tabular}

\section{CONCLUSIONS}

The use of gibberellin at a concentration of $415 \mathrm{mg} \mathrm{L}^{-1}$ accelerates the vegetative growth of Spondias tuberosa plants and assists in the formation of seedlings with better root system and xylopodium and vigorous aerial part.

\section{ACKNOWLEDGEMENTS}

Work developed with financial support through the Agreement No. 817164/2015 CAPES / PROAP.

\section{REFERENCES}

ALVARES, C. A. et al. Köppen's climate classification map for Brazil. Meteorologische Zeitschrift, 22: 711-728, 2013.

AMARO, C. L. et al. Análise do crescimento de mudas de Eucalyptus sp. submetidas a diferentes doses de giberelina. Revista Agri-Environmental Sciences, 3: 24-29, 2017.
ANDERSON, M. J. A new method for nonparametric multivariate analysis of variance. Austral Ecology, 26: 32-46, 2001.

BJÖRKLUND, S. et al. Cross-talk between gibberellin and auxin in development of Populus wood: gibberellin stimulates polar auxin transport and has a common transcriptome with auxin. The Plant Journal, 52: 499-511, 2007.

BORGES, L. P. et al. Caracterização morfofisiológica de populações de pinhão manso. Revista Agrotecnologia, 5: 75-86, 2014.

BRASIL. Ministério da Agricultura, Pecuária e Abastecimento. Plano nacional de desenvolvimento da fruticultura. Brasília, DF, 2018. 41 p.

CAVAlCANTI, N. M. S. et al. Aspectos agronômicos do meloeiro 'mandacaru' cultivado em ambiente protegido sob irrigação. Irriga, 20: 261272,2015

CRUZ, F. R. S.; ANDRADE, L. A.; FEITOSA, R. C. Produção de mudas de umbuzeiro (Spondias tuberosa Arruda Câmara) em diferentes substratos e 
tamanho de recipientes. Ciência Florestal, 26: 69$80,2016$.

DONATO, S. L. R. et al. Prospecção e avaliação de acessos de umbuzeiro. Informe agropecuário, 40: 22-38, 2019a.

DONATO, S. L. R. et al. Aspectos ecofisiológicos, morfológicos, fenológicos e de produção do umbuzeiro e da umbucajazeira. Informe agropecuário, 40: 22-38, 2019b.

EMPRESA BRASILEIRA DE PESQUISA AGROPECUÁRIA - EMBRAPA. Sistema Brasileiro de Classificação de Solos. 3 ed. Brasília, DF: Embrapa Solos, 2013. 353 p.

LIMA, M. A. C.; SILVA, S. M.; OLIVEIRA, V. R. Umbu -Spondias tuberosa. In: RODRIGUES, S.; SILVA, E. O.; BRITO, E. S. ( 1 ed.). Exotic Fruits Reference Guide, 1. ed. Inglaterra: Academic Press, 2018. v. 1, cap. 56 , p. 427-433.

LINS NETO, E. M. F. et al. Phenology of Spondias tuberosa Arruda (Anacardiaceae) under different landscape management regimes and a proposal for a rapid phenological diagnosis using local knowledge. Journal of Ethnobiology and Ethnomedicine, 9: 113, 2013.

LOPES, V. A. et al. Crescimento inicial de plantas de eucalipto tratadas com giberelina. Academic Journal, 10: 1251-1255, 2015.

MERTENS, J. et al. Spondias tuberosa Arruda (Anacardiaceae), a threatened tree of the Brazilian Caatinga? Brazilian Journal of Biology, 77: 542$552,2016$.

NUNES, E. N. et al. Local botanical knowledge of native food plants in the semiarid region of Brazil. Journal of Ethnobiology and Ethnomedicine, 14: 49-62, 2018.

PIRES, E. S. Crescimento de mudas de umbuzeiro sob doses crescentes de giberelina. 2018. $20 \mathrm{f}$. Dissertação (Mestrado em Produção Vegetal: Área de Concentração em Fisiologia da Produção Vegetal) - I nstituto Federal Baiano, Guanambi, 2018.

PORTO, A. H. et al. Giberelina e substratos na produção e qualidade de mudas de araçazeiros amarelo e vermelho. Colloquium Agrarie, 14: 3246, 2018.

R CORE TEAM. R: A language and environment for statistical computing, $\mathrm{R}$ foundation for statistical computing, Vienna, Austria. Disponível em: $<$ http://www.R-project.org/>. Acesso em: 15 set. 2018 .

SANTOS, E. F. et al. Quantificação de compostos bioativos em frutos de umbu (Spondias tuberosa Arr. Câm.) e cajá (Spondias mombin L.) nativos de alagoas. Ciência Agrícola, 16: 21-29, 2018.

SATURNINO, H. M. et al. Características botânicas do umbuzeiro e outras Spondias. Informe agropecuário, 40: 7-21, 2019.

SOKAL, R. R.; ROLPH, F. J. Biometry. 2. ed. New York: W. H. Freeman, 1995. 915 p.

SOUZA, B. I.; MENEZES, R.; ARTIGAS, R. C. Efeitos da desertificação na composição de espécies do bioma Caatinga, Paraíba/Brasil. Investigaciones Geograficas, 88: 45-69, 2015.

SYSTAT SOFTWARE. SigmaPlot for windows. Version 10.0. San Jose: Systat Software, 2006.

TAIZ, L. et al. Fisiologia Vegetal. 6 ed. Porto Alegre, RS: Artmed, 2017. 858 p.

WEISS, D.; ORI, N. Mechanisms of cross talk between gibberellin and other hormones. Plant Physiology, 144: 1240-6, 2007.

WELLBURN, A. R. The spectral determination of chlorophylls a and b, as well as total carotenoids, using various solvents with spectrophotometers of different resolution. Journal of Plant Physiology, 144: 307-313, 1994. 